\title{
A late Archaean pegmatite dyke swarm from the Isukasia area, southern West Greenland
}

\author{
H. Baadsgaard, A. P. Nutman, M. Rosing and D. Bridgwater
}

The Isukasia area is dominated by early Archaean rocks that have been discussed extensively in the geological literature (Nutman et al., 1983). These rocks were deformed and recrystallised under amphibolite facies conditions during the late Archaean regional ductile deformation (Bridgwater et al., 1976; Nutman et al., 1983). The pegmatite dykes discussed here post-date this event but were succeeded by Proterozoic basic dykes, rare granitic sheets (Kalsbeek et al., 1980; Kalsbeek \& Taylor, 1983), and then by Proterozoic faulting.

\section{Pegmatite dykes}

South of the Isua supracrustal belt a swarm of pegmatite dykes occurs around the southern part of the lake at $678 \mathrm{~m}$ (see fig. 18, Nutman, 1982). A few pegmatite dykes considered to belong to the same generation also occur in the Isua supracrustal belt and the gneisses to the north. The pegmatites are steeply dipping, have a dominant trend of $c .080^{\circ}$ and most of them are less than $10 \mathrm{~m}$ wide. On the eastern side of the lake at $678 \mathrm{~m}$ a large member of the swarm is up to $100 \mathrm{~m}$ wide, $3 \mathrm{~km}$ long and contains microcline crystals up to $1 \mathrm{~m}$ across. The pegmatites consist of microcline, plagioclase, quartz and interlayered muscovite-biotite that forms large books in some dykes. Locally, chloritised garnet occurs. Allanite crystals up to 1 $\mathrm{cm}$ long have locally grown in the wall rocks. The presence of muscovite and large allanites in wall rocks of tonalitic banded gneisses, and biotite in mafic rocks, suggests hydration and movement of alkali and light rare earth elements associated with the intrusion and crystallisation of the pegmatite dykes.

The pegmatite dykes are undeformed apart from local sheared margins. However, a few of the pegmatites occur further to the west and have been affected by movements of Proterozoic age on the Ataneq fault system.

Salmon pink and white, slightly deformed pegmatite dykes and lenses with northerly trends occur sporadically in the western side of the north-western end of the Isua supracrustal belt. These are provisionally correlated with the pegmatite swarm around the lake at $678 \mathrm{~m}$.

The dykes mostly have granitic composition (sample 236965, Table 2) but also pegmatite with higher $\mathrm{Na} / \mathrm{K}$ values occurs (sample 292145 , Table 2 ). The samples analysed were large enough (c. $5 \mathrm{~kg}$ ) relative to grain size (up to $2 \mathrm{~cm}$ ) for the $\mathrm{Na} / \mathrm{K}$ variation to be real, and not due to sampling bias. As with other pegmatite swarms, $\mathrm{Na} / \mathrm{K}$ variation could be due to $\mathrm{Na}-\mathrm{K}$ exchange with the fluid phase during and immediately after the final stages of crystallisation of the dykes. The observed alteration along the wall rocks is in accord with this suggestion.

The $\mathrm{Rb}$-Sr isotope geochemistry of seven whole rock samples of different pegmatite dykes is presented here (fig. 17). The samples scatter about a reference line of $2565 \mathrm{Ma}$ with a initial ${ }^{87} \mathrm{Sr} /{ }^{86} \mathrm{Sr}$ ratio of 0.7277 . The high initial ${ }^{87} \mathrm{Sr} /{ }^{86} \mathrm{Sr}$ value of the reference line is similar to that estimated for the average ${ }^{87} \mathrm{Sr} /{ }^{86} \mathrm{Sr}$ value of the host Amitsoq gneisses in the late Arch- 
Fig. 17. Rb-Sr whole rock isotopic data for seven samples of late pegmatite dykes from the Isukasia area.

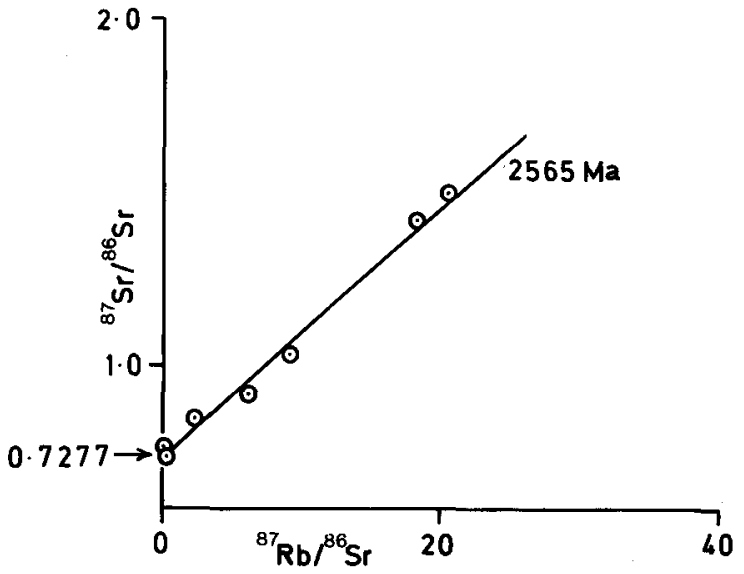

aean (Moorbath \& Pankhurst, 1976; Baadsgaard, unpublished data). This could mean that either the dykes were produced by partial melting of such a source or that the $\mathrm{Rb}$-Sr isotope chemistry of these pegmatites is predominantly a function of interaction with their country rocks. The large amount of scatter about the reference line is interpreted as most probably due to variations in ${ }^{87} \mathrm{Sr} /{ }^{86} \mathrm{Sr}$ ratios of the Amitsoq gneisses at $c .2565 \mathrm{Ma}$, rather than meaning that were intruded at appreciably different times.

Table 2. Analyses of late pegmatites from the Isukasia area

\begin{tabular}{lrrrrr}
\hline GGU sample no. & 292145 & 236965 & & 292145 & 236965 \\
\hline $\mathrm{SiO}_{2}$ & 71.42 & 72.36 & $\mathrm{Rb}$ & 59 & 139 \\
$\mathrm{TiO}_{2}$ & 0.28 & 0.29 & $\mathrm{Sr}$ & 401 & 206 \\
$\mathrm{Al}_{2} \mathrm{O}_{3}$ & 14.98 & 14.11 & $\mathrm{Ba}$ & 257 & 854 \\
$\mathrm{Fe}_{2} \mathrm{O}_{3}$ & 0.13 & 0.50 & $\mathrm{Y}$ & 2 & 11 \\
$\mathrm{FeO}_{\mathrm{MnO}}$ & 1.90 & 1.34 & $\mathrm{~Pb}$ & 19 & 39 \\
$\mathrm{MgO}_{\mathrm{CaO}}$ & 0.03 & 0.03 & $\mathrm{Zr}$ & 131 & 262 \\
$\mathrm{Na}_{2} \mathrm{O}$ & 0.70 & 0.26 & $\mathrm{Cr}$ & 8 & 6 \\
$\mathrm{~K}_{2} \mathrm{O}$ & 2.61 & 1.33 & $\mathrm{Ni}$ & 4 & $\mathrm{n.d}$. \\
$\mathrm{l.0} . \mathrm{i}$ & 5.12 & 3.99 & $\mathrm{Th}$ & 7 & 21 \\
$\mathrm{P}_{2} \mathrm{O}_{5}$ & 1.64 & 4.28 & & & \\
& 0.72 & 0.50 & & & \\
\hline
\end{tabular}

Major elements were determined by X.R.F. techniques at the Geological Survey of Greenland, and trace elements were determined by X.R.F. techniques at the University of Copenhagen.

l.o.i. loss on ignition at $1000^{\circ} \mathrm{C}$ and $\mathrm{n.d}$. not detected. 


\section{Discussion}

The major element and $\mathrm{Rb}-\mathrm{Sr}$ isotope chemistry of the pegmatite dykes suggest that they could have been formed by partial melting of quartzofeldspathic rocks, but that the original granitic compositions were somewhat modified upon intrusion, by interaction with a fluid phase and with their country rocks. The pegmatite dykes of the Isukasia area can be correlated with late Archaean granitoid bodies of Godthåbsfjord. The Isukasia pegmatite dykes clearly post-date the last regional late Archaean ductile deformation that led to straight belt development in the west and formation of large-scale southerly plunging folds. In this respect they resemble the $c$. 2550 Ma post-tectonic Qôrqut granite complex of Godthåbsfjord (Brown et al., 1981; Moorbath et al., 1981). The age of $c .2565$ Ma on this essentially undeformed swarm of pegmatites from the Isukasia area gives the younger limit to the end of regional ductile deformation under amphibolite facies conditions in the Isukasia area. Subsequent deformation, for example expressed by the Ataneq fault, was confined to discrete zones across the area. The Qôrqut granite complex represents a major event of essentially post-tectonic granite production by partial melting of the crust. The main body of the Qorqut granite complex extends south-westwards through Godthåbsfjord, as far as Ameralik and perhaps further. Recent field work and isotopic studies (Brewer et al., 1983; Chadwick et al., 1983; Brewer \& Robertson, personal communication, 1984) have confirmed that posttectonic granites contemporaneous with the Qôrqut granite complex continue to the north of Godthåbsfjord as pegmatite dyke swarms and granite sheets. The Isukasia pegmatites extend the occurrence of post-tectonic granitic bodies, possibly correlated with the Qôrqut granite complex to $50 \mathrm{~km}$ to the north of Godthåbsfjord.

Acknowledgements. Members of the Ivisârtoq mapping team from Exeter University and A. A. Garde, C. R. L. Friend and F. Kalsbeek are thanked for comments on this report during its preparation.

\section{References}

Bridgwater, D., Keto, L., McGregor, V. R. \& Myers, J. S. 1976: Archaean gneiss complex of Greenland. In Escher, A. \& Watt, W. S. (edit.) Geology of Greenland, 18-75. Copenhagen: Geol. Surv. Greenland.

Brown, M., Friend, C. R. L., McGregor, V. R. \& Perkins, W. T. 1981: The late Archaean Qôrqut granite complex of sourthern West Greenland. J. Geophys. Res. 86, 10617-10632.

Brewer, M., Coe, K. \& Robertson, S. 1983: Continuation of the mapping in the southern part of the Ivisârtoq map sheet Rap. Grønlands geol. Unders. 115, 42-48.

Chadwick, B., Crewe, M. A. \& Park, J. F. W. 1983: Field work in the north of the Ivisârtoq region, Godthåbsfjord, southern West Greenland. Rapp. Grønlands. geol. Unders. 115, 49-56.

Kalsbeek, F. \& Taylor, P. N. 1983: Anatectic origin of mid-Proterozoic granite dyke in the Isukasia area, West Greenland, $\mathrm{Pb}-\mathrm{Pb}$ and $\mathrm{Rb}-\mathrm{Sr}$ isotopic evidence. Rapp. Grønlands. geol. Unders. 115, 38-42.

Kalsbeek, F., Bridgwater, D. \& Boak, J. 1980: Evidence of mid-Proterozoic granite formation in the Isua area. Rapp. Grønlands geol. Unders. 100, 73-75.

Moorbath, S. \& Pankhurst, R. J. 1976: Further rubidium-strontium age and isotope evidence for the nature of the late Archaean plutonic event in West Greenland. Nature, Lond. 262, 124-126. 
Moorbath, S., Taylor, P. N. \& Goodwin, R. 1981: Origin of granitic magma by crustal remobilisation: $\mathrm{Rb}-\mathrm{Sr}$ and $\mathrm{Pb}-\mathrm{Pb}$ geochronology and isotope geochemistry of the late Archaean Qôrqut granite complex of southern West Greenland. Geochim. cosmichim. Acta 45, 1051-1069.

Nutman, A. P. 1982: Further work on the early Archaean rocks of the Isukasia area, southern West Greenland. Rapp. Grønlands geol. Unders. 110, 49-54.

Nutman, A. P., Bridgwater, D., Dimroth, E., Gill, R. C. O. \& Rosing, M. 1983: Field work on early $(3700 \mathrm{Ma})$ Archaean rocks of the Isua supracrustal belt and adjacent gneisses. Rapp. Grønlands geol. Unders. 112, 5-22.

H. B.,

University of Alberta,

Edmonton, Alberta,

Canada.
M. R. \& D. B., Geologisk Museum, Øster Voldgade 5-7, $D K-1350$ Copenhagen $K$.

A. P. N.,

Memorial University of Newfoundland,

St. John's, Newfoundland,

Canada.

\title{
Malene amphibolites and related anorthosites from Akugdlerssuaq, inner Godthåbsfjord, with komatiite affinities
}

\author{
Allen P. Nutman
}

Mapping by helicopter reconnaissance in 1976 (Allaart et al. 1977) and subsequent more detailed mapping in 1981 (Nutman, 1982) showed that there are several units of anorthosite with associated amphibolite on Akugdlerssuaq, inner Godthåbsfjord. The anorthosite and amphibolite units are interspersed with units of strongly deformed Amîtsoq gneisses (identified by the presence of basic dyke remains and by enclaves of banded iron formation) sheeted by younger gneisses. Most of the contacts between anorthosite and amphibolite units and the Amitsoq gneisses are clearly tectonic, whilst the remaining contacts could also be tectonic or are modified primary contacts (Nutman, 1982). The younger gneisses are of late Archaean age (Bridgwater \& Nutman, unpublished Rb-Sr isotopic data).

The field characters of the anorthosites and amphibolites were described by Nutman (1982). The most important points are summarised below:

The amphibolites are banded and contain lenses and discontinuous horizons of garnet-biotite-quartz-feldspar rock, possibly paragneiss. The anorthosites range from medium-grained varieties with distinct layering to a more homogeneous type consisting of a gabbroic matrix crowded with plagioclase megacrysts. The amphibolites and anorthosites are not intimately interlayered, but units up to a couple of hundred metres wide are adjacent to each other. In the west of the area, in an augen of low deformation, the anorthosite is suggested as having intruded, and locally reacted with garnet-biotite gneiss. The age relations between the anorthosites and amphibolites and the gneisses which intrude both are the same as those found in the Fiskenæsset and Buksefjorden regions (Kalsbeek \& Myers, 1973; Chadwick \& Coe, 